\title{
PENGARUH PROGRAM SAPTA PESONA DAN FASILITAS TERHADAPTINGKAT KUNJUNGAN OBJEK WISATA T-GARDENDI KECAMATAN DELI TUA KABUPATEN DELI SERDANG
}

\author{
Oleh : \\ Lukman Nasution $^{1)}$, Siti Anom ${ }^{2)}$, Ahmad Karim ${ }^{3)}$ \\ ${ }^{1}$ Universitas Muslim Nusantara Al Washliyah Medan \\ ${ }^{2}$ Universitas Darma Agung Medan \\ ${ }^{3}$ Universitas Pembinaan Masyarakat Indonesia \\ E-mail: \\ lukmanumnaw@gmail.com \\ anoem 08@yahoo.com \\ ahmadkarimk@yahoo.co.id
}

\begin{abstract}
This study aims to determine: (1) The effect of the Sapta Pesona Program on the Attraction of Tourist Attraction; (2) The Effect of Facilities on the Level of Tourist Attraction, and (3) The Effect of the Sapta Pesona Program and Facilities on the Visit Level of Deli Serdang T-Garden Tourism Objects. The sample of this study was taken randomly (random sampling) from all visitors of the T-Garden Tourism Object with a total of 50 visitors. This type of research is a quantitative study with a significance of 0.05. Methods of data collection in this study are in the form of Sapta Pesona Program questionnaire, Tourism Object Facilities, and Tourist Attraction Level. The results of this study were obtained that: (1) There was a very significant effect of the Sapta Pesona Program on the level of T-Garden Tourism Objects in Deli Serdang Regency (F-count = 18.487; Sig. = 0.000), (2) There was a significant effect of the Facility on The level of visit of Deli Serdang Regency T-Garden Objects (F-count $=7.754$; Sig. $=0.008$ ), and (3) There is a very significant influence of the Sapta Pesona Program and Facilities Together on the Level of Visit of the District T-Garden Attraction Deli Serdang (F-count = 9.069; Sig. =0,000). The results of this research imply that the application of the Sapta Enchantment Program in T-Garden attractions can affect the desire to visit tourists and make length of stay and increase the level of visit of T-Garden Objects in Deli Serdang Regency. With the interesting tourist attraction facilities and in accordance with the desires that are in demand, will be an attraction for tourists to visit and enjoy the facilities of T-Garden Attractions so that the needs of visitors are met to visit T-Garden Attractions.
\end{abstract}

Keywords : sapta pesona program, facilities, and level of tourist attraction 


\begin{abstract}
ABSTRAK
Penelitian ini bertujuan untuk mengetahui: (1) Pengaruh Program Sapta Pesona terhadap Tingkat Kunjungan Objek Wisata; (2)Pengaruh Fasilitas terhadap Tingkat Kunjungan Objek Wisata, dan (3) Pengaruh Program Sapta Pesona dan Fasilitas terhadap Tingkat Kunjungan Objek Wisata T-Garden Kabupaten Deli Serdang. Sampel penelitian ini diambil secara acak (random sampling) dari seluruh pengunjung Objek Wisata T-Garden dengan jumlah 50 pengunjung. Jenis penelitian ini merupakan penelitian kuantitatif dengan signifikansi 0,05. Metode pengumpulan data penelitian ini berupa kuesioner Program Sapta Pesona, Fasilitas Objek Wisata, dan Tingkat Kunjungan Objek Wisata. Hasil penelitian ini diperoleh bahwa: (1) Terdapat pengaruh yang sangat signifikan Program Sapta Pesona terhadap Tingkat Kunjungan Objek Wisata T-Garden Kabupaten Deli Serdang (F-hitung = 18,487; Sig. = 0,000), (2) Terdapat pengaruh yang signifikan Fasilitas terhadap Tingkat Kunjungan Objek Wisata T-Garden Kabupaten Deli Serdang (F-hitung =7,754; Sig. $=0,008)$, dan (3) Terdapat pengaruh yang sangat signifikan Program Sapta Pesona dan Fasilitas Secara Bersama-sama terhadap Tingkat Kunjungan Objek Wisata T-Garden Kabupaten Deli Serdang (F-hitung = 9,069; Sig. $=0,000)$. Hasil penelitan ini mengimplikasikan bahwa penerapan Program Sapta Pesona pada objek wisata T-Garden dapat mempengaruhi keinginan berkunjung wisatawan dan membuat lama tinggal serta meningkatkan tingkat kunjugan Objek Wisata T-Garden Kabupaten Deli Serdang. Dengan adanya fasilitas objek wisata yang menarik dan sesuai dengan keinginan yang sedang diminati, akan menjadi daya tarik bagi wisatawan untuk berkunjung dan menikmati fasilitas Objek Wisata T-Garden sehingga kebutuhan pengunjung terpenuhi untuk berkunjung ke Objek Wisata T-Garden.
\end{abstract}

Kata Kunci: program sapta pesona, fasilitas, dan tingkat kunjungan objek wisata.

\section{PENDAHULUAN}

Objek wisata T-Garden Resort and Ranch berada di Jalan Deli Tua, Simalingkar B, Kabupaten Deli Serdang. Objek wisata TGarden Resort and Ranch adalah tempat wisata di Kota Medan yang menggabungkan suasana Alam yang asri dan nuansa Bali yang magis, perpaduan dua unsur ini menjadikan T-Garden tempat wisata yang eksotis dan satu-satunya di Kota Medan. Objek wisata T-Garden Resort and Ranch ini memiliki fasilitas Resto, Outbound, Wisata Berkuda, Permainan anak-anak, berbagai macam tanaman dan pepohonan indah, padang rumput yang luas, sungai alam yang asli membuat pengunjung yang datang dapat menikmatinya (Sumber: Tgarden.co, 2018).

Menurut Kodhyat (2011:27) daya tarik wisata yang terdiri dari alam, budaya dan aktivitas serta peristiwa perlu mendapat perhatian sebagai modal dasar pembangunan kepariwisataan sekaligus meningkatkan citra pariwisata di Indonesia melalui program Sapta Pesona. Menurut Rahim (2012:5-6) Sapta Pesona adalah unsur yang penting dalam mengembangkan suatu objek wisata. Citra dan mutu 
pariwisata di suatu daerah atau objek wisata pada dasarnya ditentukan oleh keberhasilan dalam perwujudan Sapta Pesona daerah tersebut. Sapta Pesona merupakan tujuh kondisi yang harus diwujudkan dan dibudayakan dalam kehidupan masyarakat sehari-hari sebagai salah satu upaya untuk memperbesar daya tarik dan daya saing pariwisata Indonesia. Tujuh sudut pancaran sinar yang tersusun rapi disekeliling matahari menggambarkan unsurunsur Sapta Pesona yang terdiri dari unsur: aman, tertib, bersih, sejuk, indah, ramah dan kenangan. Dengan adanya penerapan Sapta Pesona pada suatu daerah tujuan pariwisata atau destinasi dapat mempengaruhi keinginan berkunjung wisatawan dan membuat lama tinggal. Dengan harapan bahwa dengan adanya program Sapta Pesona citra pariwisata dan destinasi wisata Indonesia dapat meningkat.

\section{Sebagaimana}

UndangUndang No. 10 Tahun 2009 tentang Kepariwisataan dalam mewujudkan daerah tujuan pariwisata disebut bahwa Daerah Tujuan Pariwisata atau Destinasi Pariwisata adalah kawasan geografis yang berada dalam satu atau lebih wilayah administratif yang didalamnya terdapat daya tarik wisata, fasilitas umum, fasilitas pariwisata, aksesibilitas, serta masyarakat yang saling terkait dan melengkapi terwujudnya kepariwisataan. Berdasarkan hal tersebut, faktor fasilitas memiliki peranan yang sangat penting terhadap peningkatan tingkat kunjungan objek wisata.

Objek wisata merupakan bagian yang sangat penting dalam perkembangan sebuah daerah tujuan wisata, Objek wisata yang baik dapat memberikan opini yang positif terhadap wisatawan potensial untuk berkunjung ke suatau destinasi atau daerah tujuan wisata melalui fasilitas. Apabila wisatawan merasakan kepuasan yang tinggi maka akan mendorong citra menjadi positif sehingga wisatawan akan merekomendasikan

(mengkomunikasikan) kepada wistawan potensial lainnya. Suwantoro (2000:57) menyatakan bahwa fasilitas pariwisata terdiri dari akomodasi, restauran, usaha rekreasi dan hiburan, transportasi serta sarana lain seperti souvenir shop, penyedia air dan sarana toilet. Sedangkan akomodasi adalah sarana untuk menyediakan pelayanan penginapan yang dapat dilengkapi dengan pelayanan makan dan minum serta jasa lainnya. Objek wisata T-Garden Resort and Ranch menyajikan fasilitas berupa ubud resto, resto area, bale begong, gazebo, river area, outbound, flying fox, wisata berkuda, naik delman, dan permainan anakanak (Sumber: tgarden.co, 2018). Objek wisata T-Garden Resort and Ranch ini memiliki luas 24 hektar. Rata-rata pengunjung tiap harinya dapat mencapai 200 lebih pengunjung, bahkan di hari libur (weekend) bisa mencapai angka 1000-2000 pengunjung per hari (Sumber: Tribun Medan, 2018).

$$
\text { Mill }
$$

mengemukakan bahwa fasilitas memiliki fungsi untuk memenuhi kebutuhan wisatawan selama tinggal untuk sementara waktu di daerah tujuan wisata yang dikunjungi. Fasilitas merupakan faktor yang secara nyata mempengaruhi konsumen untuk mengkonsumsi 
produk yang ditawarkan. Dengan tersedianya sarana maka akan mendorong calon wisatawan untuk berkunjung dan menikmati objek wisata dengan waktu yang relatif lama. Sammeng (2001:39) menyatakan bahwa salah satu hal penting untuk mengembangkan pariwisata adalah melalui fasilitas (kemudahan). Tidak jarang wisatawan berkunjung ke suatu tempat atau daerah atau negara, karena tertarik oleh kemudahankemudahan yang bisa diperoleh melalui fasilitas. Yoeti (2003:56) juga mengemukakan bahwa fasilitas wisata adalah semua fasilitas yang fungsinya memenuhi kebutuhan wisatawan yang tinggal untuk sementara waktu di daerah tujuan wisata yang dikunjunginya, dimana mereka dapat santai menikmati dan berpartisipasi dalam kegiatan yang tersedia di daerah tujuan wisata tersebut. Fasilitas objek wisata yang menarik dan sesuai dengan keinginan yang sedang diminati, akan menjadi daya tarik bagi wisatawan untuk berkunjung dan menikmati fasilitas tersebut, selain itu kebersihan, kelancaran dan jaminan keamanan dari fasilitas juga menjadi nilai tambah untuk menarik konsumen untuk berkunjung. Dengan demikian bentuk fasilitas dan pelayanan (facilities and services) yang tersedia pada suatu daerah tujuan wisata yang dapat memuaskan kebutuhan dan keinginan wisatawan selama mereka berkunjung di daerah tujuan wisata tersebut.

Menurut Faradisa, Budi, dan Minarsih (2016:6) menyatakan bahwa fasilitas adalah penyediaan perlengkapan-perlengkapan fisik untuk memberi kemudahan kepada konsumen untuk melaksanakan aktivitas-aktivitas sehingga kebutuhan konsumen dapat terpenuhi. Perkasa (2017:14-20) menyatakan bahwa efektivitas peningkatan kunjungan wisatawan adalah suatu upaya yang dilakukan oleh pemerintah dengan cara meningkatkan daya tarik wisata, seperti mengusahakan, mengelola dan membuat obyek-obyek baru sebagai obyek dan daya tarik wisata, agar wisatawan ingin mengunjungi serta mendapatkan suatu pengalaman tertentu dalam kunjungannya tersebut. Dalam upaya untuk mempertahankan bahkan meningkatkan jumlah kunjungan wisatawan, sebagaimana kebijakan pemerintah dalam penyelenggaraan program Sapta Pesona tersebut sudah lama dicanangkan dan tetap menjadi harapan bagi setiap daerah tujuan wisata agar Sapta Pesona dapat terlaksana sesuai dengan yang diharapkan. Selain itu, program sapta pesona juga didukung oleh visi pembangunan kepariwisataan nasional sampai dengan tahun 2025 yaitu: terwujudnya Indonesia sebagai destinasi pariwisata berkelas dunia, berdaya saing, berkelanjutan, mampu mendorong pembangunan daerah, dan kesejahteraan masyarakat.

Untuk mewujudkan visi tersebut, maka misi pembangunan kepariwisataan Indonesia sampai dengan tahun 2025 adalah: (1) mengembangkan industri pariwisata yang efisien, berdaya saing, kredibel, mensinergikan kemitraan antar usaha, dan bertanggungjawab terhadap lingkungan alam dan sosial budaya,2) mengembangkan destinasi pariwisata berkelas dunia, berdaya 
saing, berwawasan lingkungan, meningkatkan pendapatan daerah, dan meningkatkan kesejahteraan masyarakat, (3) mengembangkan pemasaran pariwisata yang unggul, efektif, dan bertanggung jawab untuk meningkatkan kunjungan wisatawan, baik wisatawan nusantara maupun wi satawan mancanegara, dan(4) mengembangkan kelembagaan dan tata kelola kepariwisataan yang efektif dan efisien serta mampu mendorong terwujudnya pembangunan industri, destinasi, dan pemasaran pariwisata yang berdaya saing dan berkelanjutan (Marsongko, 2010). Tingkat kunjungan wisata pada suatu tempat akan berpengaruh terhadap day Tarik objek wisata yang ditawarkan kelompok masyarakat mupun pemerintah daerah untuk mempromosikan wisata didaerahnya Sianipar C \& Liyushiana L (2019), Perwirawati E \& Juprianto J (2019.

Dengan perkembangan kepariwisataan secara global serta peningkatan arus kunjungan wisatawan internasional, secara tidak langsung telah berdampak kepada tuntutan penyediaan komponen industri pariwisata. Keberhasilan pengembangan sektor kepariwisataan, akan meningkatkan perannya dalam penerimaan daerah (Rahma, dan Handayani, 2013:1-2). Berdasarkan uraian dari latar belakang masalah tersebut, Program Sapta Pesona memiliki peranan yang sangat penting dan sangat diharapkan dalam meningkatkan kesadaran, rasa tanggung jawab segenap lapisan masyarakat dalam bertindak dan mewujudkannya dalam kehidupan mereka sehari-hari khususnya pada destinasi wisata. Oleh sebab itu, untuk mengkaji peranan Sapta
Pesona dalam pengembangan pariwisata serta fasilitasnya, maka penulis tertarik untuk melakukan penelitian tentang "Pengaruh Program Sapta Pesona dan Fasilitas terhadap Tingkat Kunjungan Objek Wisata T-Garden di Kecamatan Deli Tua Kabupaten Deli Serdang."Rumusan masalah dalam penelitian ini adalah:

1. Apakah terdapat Pengaruh Program Sapta Pesona terhadap Tingkat Kunjungan Objek Wisata T-Garden di Kecamatan Deli Tua Kabupaten Deli Serdang?

2. Apakah terdapat Pengaruh Fasilitas terhadap Tingkat Kunjungan Objek Wisata TGarden di Kecamatan Deli Tua Kabupaten Deli Serdang?

3. Apakah terdapat Pengaruh Program Sapta Pesona dan Fasilitas Secara Bersamasamaterhadap Tingkat Kunjungan Objek Wisata T-Garden di Kecamatan Deli Tua Kabupaten Deli Serdang?

\section{TINJAUAN PUSTAKA \\ Kunjungan Objek Wisata}

Menurut International Union

of Official Travel Organization (IUOTO), yaitu organisasi internasional penyelenggara wisata resmi, definisi pengunjung yaitu setiap orang yang datang ke suatu negara atau tempat tinggal lain dan biasanya dengan maksud apapun kecuali untuk melakukan pekerjaan yang menerima upah. Pengertian yang sama disampaikan oleh World Tourism Organization (WTO), organisasi pariwisata dunia, yang dimaksud dengan pengunjung (visitor) untuk tujuan statistik, yaitu setiap orang yang mengunjungi suatu 
negara yang bukan merupakan negaranya sendiri dengan alasan apapun juga kecuali untuk mendapatkan pekerjaan yang dibayar oleh negara yang dikunjunginya (Suyadi, 2015:160).

Menurut Undang-Undang Republik Indonesia Nomor 10 Tahun 2009 tentang Kepariwisataan yang dimaksud dengan wisata adalah kegiatan perjalanan yang dilakukan oleh seseorang atau sekelompok orang dengan mengunjungi tempat tertentu untuk tujuan rekreasi, pengembangan pribadi, atau mempelajari keunikan daya tarik wisata yang dikunjungi dalam jangka waktu sementara. Menurut Kesrul (2003:4) bahwa wisata adalah kegiatan di luar kegiatan rutin seharihari, seperti bekerja atau sejenisnya. Sedangkan pengertian wisatawan adalah orang yang melakukan wisata.

Menurut Suyadi (2015:160) ada dua kategori pengunjung, yaitu: (1) wisatawan (tourist) yaitu pengunjung yang tinggal sementara sekurang-kurangnya selama 24 jam di negara yang kunjunginya dan tujuan perjalanannya dapat digolongkan ke dalam klasifikasi sebagai (a) pesiar (leisure), untuk keperluan rekreasi, liburan, kesehatan, studi, keagamaan dan olahraga; dan (b) hubungan dagang (business), keluarga, konferensi, misi, dan lain sebagainya, dan (2) pelancong (exursionist) yaitu pengunjung sementara yang tinggal di suatu negara yang dikunjungi dalam waktu kurang dari 24 jam. Sedangkan wisatawan berdasarkan daerah tujuannya digolongkan menjadi dua, yaitu: (1) wisatawan mancanegara adalah wisatawan yang dalam perjalanannya memasuki daerah negara yang bukan negaranya sendiri, dan (2) wisatawan domestik adalah wisatawan yang dalam perjalanannya hanya di dalam negeri.

Dengan demikian kunjungan wisata merupakan kegiatan wisatawan baik secara perorangan maupun kelompok yang bertujuan untuk rekreasi, pengembangan pribadi, atau mempelajari keunikan daya tarik wisata yang dikunjungi dalam jangka waktu sementara. Adapun indikator dari kunjungan wisata berupa: (1) pemanfaatan sumber daya alam, historis, dan budaya, (2) pengembangan kepariwisataan direncanakan dan dikelola dengan baik, (3) memelihara kualitas lingkungan objek wisata, (4) kepuasan wisatawan yang tinggi terhadap daerah tujuan wisata, dan (5) manfaat dari kepariwisataan bagi masyarakat secara menyeluruh.

\section{Program Sapta Pesona}

Program Sapta Pesona yang dicanangkan oleh Pemerintah Indonesia pada tahun 1989 dengan Surat Keputusan Menteri Pariwisata, Pos dan Telekomunikasi Nomor: KM.5/UM.209/MPPT-89 tentang Pedoman Penyelenggaraan Sapta Pesona sebagai payung tindakan yang unsur-unsurnya terdiri dari: aman, tertib, bersih, sejuk, indah, ramah dan kenangan. Sapta Pesona merupakan kondisi yang harus diwujudkan dalam rangka menarik minat wisatawan berkunjung kesuatu daerah.

Pada tahun 2012 Program Sapta Pesona berkembang dengan tujuan mendorong dan mengembangkan industri pariwisata Indonesia. Dimana Sapta Pesona adalah unsur yang penting dalam 
mengembangkan suatu objek wisata. Citra dan mutu pariwisata di suatu daerah atau objek wisata pada dasarnya ditentukan oleh keberhasilan dalam perwujudan Sapta Pesona daerah tersebut. Sapta Pesona merupakan tujuh kondisi yang harus diwujudkan dan dibudayakan dalam kehidupan masyarakat sehari-hari sebagai salah satu upaya untuk memperbesar daya tarik dan daya saing pariwisata Indonesia. Sapta Pesona merupakan jabaran konsep Sadar Wisata yang terkait dengan dukungan dan peran masyarakat sebagai tuan rumah dalam upaya untuk menciptakan lingkungan dan suasana kondusif yang mampu mendorong tumbuh dan berkembangnya industri pariwisata melalui perwujudan tujuh unsur dalam Sapta Pesona tersebut. Logo Sapta Pesona berbentuk matahari tersenyum yang menggambarkan semangat hidup dan kegembiraan. Tujuh sudut pancaran sinar yang tersusun rapi di sekeliling matahari menggambarkan unsur-unsur Sapta Pesona yang terdiri dari unsur: aman, tertib, bersih, sejuk, indah, ramah dan kenangan (Rahim, 2012:11-16).

$$
\text { Adapun penjelasan lebih }
$$

lanjut dapat diuraikan sebagai berikut:

\section{Ad.a. Aman}

Merupakan suatu kondisi lingkungan di destinasi pariwisata atau daerah tujuan wisata yang memberikan rasa tenang, bebas dari rasa takut dan kecemasan bagi wisatawan dalam melakukan perjalanan atau kunjungan ke daerah tersebut. Bentuk aksi yang perlu diwujudkan antara lain dengan sikap yang tidak menganggu kenyamanan wisatawan; menolong dan melindungi wisatawan; menunjukkan sifat bersahabat terhadap wisatawan; memelihara keamanan lingkungan; membantu memberi informasi kepada wisatawan; menjaga lingkungan yang bebas dari bahaya penyakit menular, dan meminimalkan resiko kecelakaan dalam penggunaan fasilitas publik.

\section{Ad.b. Tertib}

Merupakan suatu kondisi lingkungan dan pelayanan di destinasi pariwisata/daerah tujuan wisata yang mencerminkan sikap disiplin yang tinggi serta kualitas fisik dan layanan yang konsisten dan teratur serta efisien sehingga memberikan rasa nyaman dan kepastian bagi wisatawan dalam melakukan perjalanan atau kunjungan ke daerah tersebut. Bentuk aksi yang perlu diwujudkan antara lain: mewujudkan budaya antri; memelihara lingkungan dengan mentaati peraturan yang berlaku; disiplin waktu/tepat waktu, dan serba jelas, teratur, rapi dan lancar.

\section{Ad.c. Bersih}

Suatu kondisi lingkungan serta kualitas produk dan pelayanan di daerah tujuan wisata yang mencerminkan keadaan yang sehat sehingga memberikan rasa nyaman dan senang bagi wisatawan dalam melakukan perjalanan atau kunjungan ke daerah tersebut. Bentuk aksi yang perlu diwujudkan antara lain: tidak membuang sampah sembarangan; menjaga kebersihan lingkungan objek wisata; menjaga lingkungan yang bebas dari polusi udara; menyiapkan sajian makanan dan minuman yang higienis; menyiapkan perlengkapan penyajian 
makanan dan minuman yang bersih, dan pakaian dan penampilan petugas yang bersih dan rapi.

\section{Ad.d. Sejuk}

Suatu kondisi di daerah tujuan wisata yang mencerminkan keadaan yang sejuk dan teduh yang akan memberikan perasaan nyaman bagi wisatawan dalam melakukan kunjungannya ke daerah tersebut. Bentuk aksi yang perlu diwujudkan antara lain: melaksanakan penghijauan dengan menanam pohon; memelihara penghijauan di lingkungan objek wisata, dan; menjaga kondisi sejuk dalam berbagai area di daerah tujuan wisata.

\section{Ad.e. Indah}

Suatu kondisi di daerah tujuan wisata yang mencerminkan keadaan yang indah dan menarik dan memberikan kesan yang mendalam bagi wisatawan sehingga mewujudkan potensi kunjungan ulang serta mendorong promosi ke pasar wisata yang lebih luas. Bentuk Aksi yang perlu diwujudkan antara lain: menjaga objek wisata dalam tatanan yang estetik, alami dan harmoni; menata lingkungan secara teratur, dan menjaga keindahan vegetasi, tanaman hias dan peneduh.

\section{Ad.f. Ramah}

Suatu kondisi lingkungan
yang bersumber dari sikap
masyarakat di destinasi pariwisata
yang mencerminkan suasana yang
akrab dan terbuka. Bentuk Aksi yang
perlu diwujudkan: bersikap sebagai
tuan rumah yang baik serta selalu
membantu wisatawan; memberi
informasi tentang adat istiadat secara

sopan; menunjukkan sikap menghargai dan toleransi terhadap wisatawan, dan memberikan senyum yang tulus.

\section{Ad.g. Kenangan}

Suatu bentuk pengalaman yang berkesan di destinasi pariwisata yang akan memberikan rasa senang dan kenangan yang indah bagi wisatawan. Bentuk aksi yang perlu diwujudkan: menggali dan mengangkat keunikan budaya lokal; menyajikan makanan dan minuman khas lokal yang bersih dan sehat; menyediakan cinderamata yang menarik, unik/khas serta mudah dibawa.

Kodhyat

menyatakan bahwa daya tarik wisata yang terdiri dari alam, budaya dan aktivitas serta peristiwa perlu mendapat perhatian sebagai modal dasar pembangunan kepariwisataan sekaligus meningkatkan citra pariwisata di Indonesia melalui program Sapta Pesona. Dengan adanya penerapan Sapta Pesona pada suatu daerah tujuan pariwisata atau destinasi dapat mempengaruhi keinginan berkunjung wisatawan dan membuat lama tinggal. Dengan harapan bahwa dengan adanya program Sapta Pesona maka tingkat kunjungan objek wisata dapat meningkat.

Menurut Rahim (2012:5-6)

Program Sapta Pesona perlu diterapkan di semua Daerah Tujuan Wisata di Indonesia; unsur tersebut kemudian dikemukakan kembali dalam buku yang dikeluarkan oleh Kementerian Kepariwisataan dan Kebudayaan bahwa: Sapta Pesona merupakan jabaran konsep Sadar Wisata yang terkait dengan 
dukungan dan peran masyarakat sebagai tuan rumah dalam upaya untuk menciptakan lingkungan dan suasana kondusif yang mampu mendorong tumbuh dan berkembangnya industri pariwisata, melalui perwujudan unsur aman, tertib, bersih, sejuk, indah, ramah, dan unsur kenangan. Tujuh unsur pesona yang harus diwujudkan bagi terciptanya lingkungan yang kondusif dan ideal bagi berkembangnya kegiatan kepariwisataan di suatu tempat dapat mendorong tumbuhnya minat wisatawan untuk berkunjung. Dengan terwujudnya ketujuh unsur Sapta Pesona dalam pengembangan kepariwisataan di daerah akan bermuara pada:meningkatnya minat kunjungan wisatawan ke destinasi, tumbuhnya iklim usaha kepariwisataan yang prospektif, dan meningkatnya lapangan pekerjaan dan peluang pendapatan, serta dampak ekonomi multi ganda pariwisata bagi masyarakat.

Sapta Pesona merupakan jabaran konsep Sadar Wisata yang terkait dengan dukungan dan peran masyarakat sebagai tuan rumah dalam upaya untuk menciptakan lingkungan dan suasana kondusif yang mampu mendorong tumbuh dan berkembangnya industri pariwisata melalui perwujudan tujuh unsur dalam Sapta Pesona tersebut. Masyarakat yang sadar wisata memiliki sikap dan tingkah laku yang sesuai dengan Sapta Pesona pariwisata. Sehingga Sapta Pesona yang merupakan jabaran konsep Sadar Wisata sangat terkait dengan dukungan dan peran masyarakat sebagai tuan rumah dalam upaya untuk menciptakan lingkungan dan suasana kondusif yang mampu mendorong tumbuh dan berkembangnya industri pariwisata melalui perwujudan tujuh unsur dalam Sapta Pesona tersebut. Jika masyarakat tidak mendukung Sapta Pesona pariwisata maka wisatawan tidak akan mendapatkan ketenangan dalam berwisata.

$\begin{array}{cccr} & \text { Dengan demikian } & \text { Program } \\ \text { Sapta } & \text { Pesona merupakan } & \text { upaya } \\ \text { untuk } & \text { mendorong } & \text { dan }\end{array}$ mengembangkan industri pariwisata Indonesia melalui dukungan dan peran masyarakat dalam menciptakan lingkungan dan suasana kondusif di daerah tujuan pariwisata atau destinasi wisata dengan menerapkan program Sapta Pesona, yang terdiri dari: unsur aman, tertib, bersih, sejuk, indah, ramah, dan unsur kenangan. Adapun indikator program Sapta Pesona tersebut antara lain: (a) unsur aman, indikatornya: menjaga kenyamanan wisatawan, menolong wisatawan, melindungi wisatawan, menunjukkan sifat bersahabat terhadap wisatawan, memelihara keamanan lingkungan, membantu memberi informasi kepada wisatawan, menjaga lingkungan yang bebas dari bahaya penyakit menular, dan meminimalkan resiko kecelakaan dalam penggunaan fasilitas publik; (b) unsur tertib, indikatornya: mewujudkan budaya antri, memelihara lingkungan, mentaati peraturan yang berlaku, disiplin waktu/tepat waktu, peraturan tata tertib jelas, memelihara keteraturan dalam ketertiban, memelihara kerapian dalam ketertiban, dan mengutamakan kelancaran dalam ketertiban; (c) unsur bersih, 
indikatornya: membuang sampah pada tempatnya, menjaga kebersihan lingkungan objek wisata, menjaga lingkungan yang bebas dari polusi udara, menyiapkan sajian makanan yang higienis, menyiapkan sajian minuman yang higienis, menyiapkan perlengkapan penyajian makanan yang bersih, menyiapkan perlengkapan penyajian minuman yang bersih, pakaian petugas yang bersih, dan penampilan petugas yang rapi; (d) unsur sejuk, indikatornya: melaksanakan penghijauan dengan menanam pohon, memelihara penghijauan di lingkungan objek wisata, dan menjaga kondisi sejuk dalam berbagai area di daerah tujuan wisata; (e) unsur indah, indikatornya: menjaga objek wisata dalam tatanan yang estetik, menjaga objek wisata dalam tatanan yang alami, menjaga objek wisata dalam tatanan yang harmoni, menata lingkungan secara teratur, menjaga keindahan vegetasi, menjaga keindahan tanaman hias, dan menjaga keindahan keteduhan; (f) unsur ramah, indikatornya: bersikap sebagai tuan rumah yang baik, selalu membantu wisatawan, memberi informasi tentang adat istiadat secara sopan, menunjukkan sikap menghargai terhadap wisatawan, menunjukkan sikap toleransi terhadap wisatawan, dan memberikan senyum yang tulus; (g) unsur kenangan, indikatornya: menggali keunikan budaya lokal, mengangkat keunikan budaya lokal, menyajikan makanan khas lokal yang bersih, menyajikan minuman khas lokal yang bersih, menyajikan makanan khas lokal yang mengandung kesehatan untuk wisatawan, menyajikan minuman khas lokal yang mengandung kesehatan untuk wisatawan, menyediakan cinderamata yang menarik bagi wisatawan, menyediakan cinderamata yang unik/khas bagi wisatawan, dan menyediakan cinderamata yang praktis mudah dibawa wisatawan.

\section{Fasilitas Pariwisata}

Fasilitas merupakan sarana dan prasarana yang mendukung operasional objek wisata untuk mengakomodasi segala kebutuhan wisatawan. Mill (2000:12) menyatakan bahwa fasilitas memiliki fungsi untuk memenuhi kebutuhan wisatawan selama tinggal untuk sementara waktu di daearah tujuan wisata yang dikunjungi. Fasilitas merupakan faktor yang secara nyata mempengaruhi konsumen untuk mengkonsumsi produk yang ditawarkan. Dengan tersedianya sarana maka akan mendorong calon wisatawan untuk berkunjung dan menikmati objek wisata dengan waktu yang relatif lama.

Menurut Suwantoro (2000:57) fasilitas pariwisata terdiri dari akomodasi, restauran, usaha rekreasi dan hiburan, transportasi serta sarana lain seperti souvenir shop, penyedia air dan sarana toilet. Akomodasi adalah sarana untuk menyediakan pelayanan penginapan yang dapat dilengkapi dengan pelayanan makan dan minum serta jasa lainnya. Sammeng (2001:39) menyatakan bahwa salah satu hal penting untuk mengembangkan pariwisata adalah melalui fasilitas (kemudahan). Tidak jarang wisatawan berkunjung ke suatu tempat atau daerah atau negara, karena tertarik oleh kemudahankemudahan yang bisa diperoleh 
melalui fasilitas. Yoeti (2003:56) juga mengemukakan bahwa fasilitas wisata adalah semua fasilitas yang fungsinya memenuhi kebutuhan wisatawan yang tinggal untuk sementara waktu di daerah tujuan wisata yang dikunjunginya, dimana mereka dapat santai menikmati dan berpartisipasi dalam kegiatan yang tersedia di daerah tujuan wisata tersebut.

Menurut Sumayang (2003:124) menjelaskan beberapa indikator yang perlu diperhatikan dalam penyediaan fasilitas, antara lain:

a. Kelengkapan, kebersihan, dan kerapian fasilitas yang ditawarkan, yaitu: keadaan fasilitas perusahaan yang dilengkapi oleh atribut yang menyertainya dan didukung dengan kebersihan dan kerapian saat konsumen menggunakan fasilitas tersebut.

b. Kondisi dan fungsi fasilitas yang akan ditawarkan, yaitu: fasilitas yang berfungsi dengan baik dan tidak mengalami kerusakan.

c. Kemudahan menggunakan fasilitas yang ditawarkan, yaitu: fasilitas yang ditawarkankepada konsumen adalah fasilitas yang sudah familier bagi konsumen sehinggakonsumen dapat menggunakannya dengan mudah.

d. Kelengkapan alat yang digunakan adalah alat yang digunakan oleh konsumen sesuai dengan spesifikasinya.

Menurut teori Spillane (dalam Mukhlas, 2008:32) fasilitas dikelompokkan menjadi tiga bagian, yaitu:

a. Fasilitas utama, merupakan sarana yang sangat dibutuhkan dan dirasakan sangat perlu selama pengunjung berada disuatu objek wisata.

b. Fasilitas pendukung, sarana yang pada proporsinya sebagai pelengkap fasilitas utama sehingga wisatawan akan merasa lebih betah.

c. Fasilitas penunjang, pada dasarnya merupakan sarana yang bersifat sebagai pelengkap utama sehingga wisatawan terpenuhi apapun kebutuhan selama mengunjungi.

$$
\text { Yoeti }
$$

mengemukakan bahwa bentuk fasilitas dan pelayanan (facilities and services) yang tersedia pada suatu daerah tujuan wisata yang dapat memuaskan kebutuhan dan keinginan wisatawan selama mereka berkunjung di daerah tujuan wisata tersebut. Lupioadi dan Hamdani (2008:148) juga menyatakan bahwa fasilitas merupakan penampilan, kemampuan sarana prasarana, dan keadaan lingkungan sekitarnya dalam menunjukkan eksistensinya kepada eksternal yang meliputi fasilitas fisik (gedung), perlengkapan dan peralatan.

$$
\text { Menurut Sulastiyono }
$$

(2006:11) mengemukakan bahwa fasilitas adalah penyediaan perlengkapan-perlengkapan fisik untuk memberikan kemudahan kepada para tamu dalam melaksanakan aktivitas-aktivitasnya atau kegiatan-kegiatannya, sehingga kebutuhan-kebutuhan tamu dapat terpenuhi. Faradisa, Budi, dan Minarsih (2016:6) juga menyatakan bahwa fasilitas adalah penyediaan perlengkapan-perlengkapan fisik untuk memberi kemudahan kepada konsumen untuk melaksanakan 
aktivitas-aktivitas

kebutuhan konsumen dapat terpenuhi.

Dengan demikian fasilitas merupakan sarana dan prasarana yang mendukung operasional objek wisata untuk mengakomodasi segala kebutuhan wisatawan.Fasilitas objek wisata yang menarik dan sesuai dengan keinginan yang sedang diminati, akan menjadi daya tarik bagi wisatawan untuk berkunjung dan menikmati fasilitas tersebut sehingga kebutuhan pengunjung terpenuhi, selain itu kebersihan, kelancaran dan jaminan keamanan dari fasilitas juga menjadi nilai tambah untuk menarik konsumen untuk berkunjung.

\section{METODE PENELITIAN}

Penelitian ini dilakukan di Objek Wisata T-Garden Kabupaten Deli Serdang pada bulan Mei sampai dengan Juli 2018. Populasi penelitian ini adalah seluruh pengunjung Objek WisataT-Garden berjumlah 100 pengunjung. Sampel penelitian ini diambil secara acak (random sampling) dari seluruh pengunjung Objek Wisata T-Garden dengan jumlah 50 pengunjung. Jenis penelitian ini merupakan penelitian kuantitatif. Variabel penelitian ini terdiri dari variabel bebas dan terikat. Variabel bebas adalah Program Sapta Pesona (X-1), dan fasilitas objek wisata (X-2). Sedangkan variabel terikatnya adalah tingkat kunjungan objek wisata T-Garden (Y).

\section{Metode Pengumpulan Data}

Metode pengumpulan data penelitian ini berupa kuesionerProgram Sapta Pesona,
Fasilitas Objek Wisata, dan Tingkat Kunjungan Objek Wisata.

\section{Teknik Analisis Data}

Teknik analisis data dalam penelitian ini dengan menggunakan: Uji t (Parsial), Uji F (Serempak), dan Uji Koefisien Determinasi (RSquare/ $\mathrm{R}^{2}$ ). Penghitungan uji analisis dalam penelitian ini dilakukan dengan menggunakan bantuan program Statistical Package for Social Science (SPSS).

HASIL PENELITIAN

Karakteristik Responden Berdasarkan Jenis Kelamin

KarakteristikRespondenBerda sarkan Jenis Kelamin disajikan pada Tabel 1.

\section{Tabel1.}

\begin{tabular}{cl} 
Karakteristik & \multicolumn{2}{c}{ Responden } \\
& $\begin{array}{l}\text { Berdasarkan Jenis } \\
\text { Kelamin }\end{array}$
\end{tabular}

\begin{tabular}{|l|c|c|}
\hline Jenis Kelamin & Frekuensi & Persen (\%) \\
\hline Laki-laki & 21 & 42,00 \\
\hline Perempuan & 29 & 58,00 \\
\hline Jumlah & $\mathbf{5 0}$ & $\mathbf{1 0 0 , 0 0}$ \\
\hline
\end{tabular}

Karakteristik

Berdasarkan Usia

Karakteristik Responden

Berdasarkan Usia disajikan pada Tabel 2.

Tabel 2.

Karakteristik Responden

Berdasarkan Jenis Kelamin

\begin{tabular}{|c|c|c|}
\hline Usia & Frekuensi & Persen (\%) \\
\hline$\leq 20$ tahun & 9 & 18,00 \\
\hline $21-30$ tahun & 25 & 50,00 \\
\hline $31-40$ tahun & 14 & 28,00 \\
\hline $41-50$ tahun & 2 & 4,00 \\
\hline Jumlah & $\mathbf{5 0}$ & $\mathbf{1 0 0 , 0 0}$ \\
\hline
\end{tabular}

Deskripsi Data Program Sapta Pesona 
Tabel 3.

KategoriProgram Sapta Pesona

\begin{tabular}{|c|c|c|}
\hline Skor & Kategori & $\begin{array}{c}\text { Skor Rata-rata } \\
\text { Program Sapta } \\
\text { Pesona } \\
\end{array}$ \\
\hline $184-250$ & Tinggi & \multirow{3}{*}{$\begin{array}{c}220,56 \\
\text { (Kategori } \\
\text { Tinggi) }\end{array}$} \\
\hline $117-183$ & Sedang & \\
\hline $50-116$ & Rendah & \\
\hline
\end{tabular}

\section{Deskripsi Data Fasilitas Objek} Wisata

Tabel 4.

Kategori Fasilitas Objek Wisata TGarden

\begin{tabular}{|c|c|c|}
\hline Skor & Kategori & $\begin{array}{c}\text { Skor Rata-rata } \\
\text { Fasilitas Objek } \\
\text { Wisata }\end{array}$ \\
\hline $41-55$ & Tinggi & \multirow{3}{*}{$\begin{array}{c}45,92 \\
\text { (Kategori } \\
\text { Tinggi) }\end{array}$} \\
\hline $26-40$ & Sedang & \\
\hline $11-25$ & Rendah & \\
\hline
\end{tabular}

\section{Deskripsi Data Tingkat \\ Kunjungan Objek Wisata}

Tabel 5.

Kategori Tingkat Kunjungan Objek

Wisata T-Garden

\begin{tabular}{|c|c|c|}
\hline Skor & Kategori & $\begin{array}{c}\text { Skor Rata-rata } \\
\text { Tingkat } \\
\text { Kunjungan } \\
\text { Objek Wisata }\end{array}$ \\
\hline $19-25$ & Tinggi & \multirow{2}{*}{$\begin{array}{c}21,88 \\
\text { (Kategori Tinggi) }\end{array}$} \\
\hline $12-18$ & Sedang & \\
\hline $5-11$ & Rendah & \\
\hline
\end{tabular}

Hasil Uji Hipotesis
1. Pengaruh Program Sapta
Pesona terhadap Tingkat
Kunjungan Objek Wisata

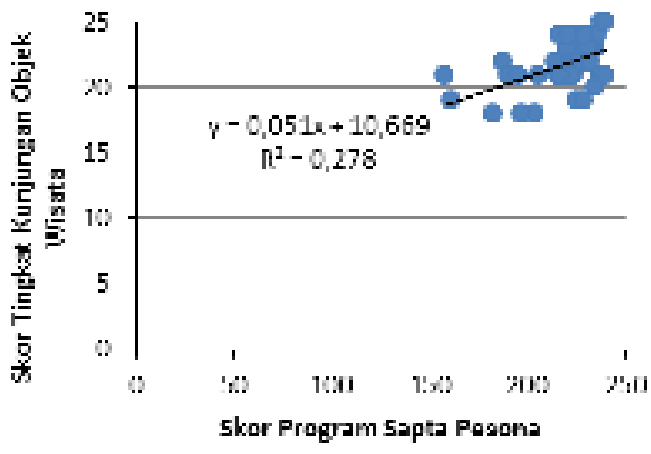

Persamaan garis linier antara Program Sapta Pesona terhadap Tingkat Kunjungan Objek Wisata adalah $\hat{Y}=0,051 \mathrm{X}_{1}+10,669$ dengan nilai koefisien determinasi $\mathrm{R}^{2}$ sebesar 0,278. Maka, Terdapat hubungan positif antara Program Sapta Pesona terhadap Tingkat Kunjungan Objek Wisata T-Gardensebesar 27,8\%.

Berdasarkan hasil uji statistik regresi diperoleh:

1. Secara bersama-sama terdapat pengaruh yang sangat signifikan Program Sapta Pesona terhadap Tingkat Kunjungan Objek WisataT-Garden Kabupaten Deli Serdang (F-hitung $=18,487$; Sig. $=0,000)$.

2. Variabel Program Sapta Pesona secara parsial berpengaruh sangat signifikan terhadap Tingkat Kunjungan Objek Wisata T-Garden Kabupaten Deli Serdang (t-hitung $=4,300$; Sig. $=0,000)$.

2. Pengaruh Fasilitas terhadap Tingkat Kunjungan Objek Wisata 


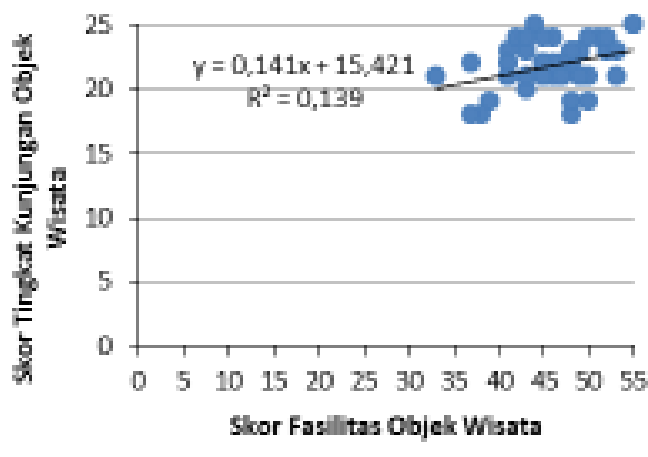

Persamaan garis linier antara Fasilitas terhadap Tingkat Kunjungan Objek Wisata adalah $\hat{Y}=$ $0,141 \mathrm{X}_{2}+15,421$. dengan nilai koefisien determinasi $\mathrm{R}^{2}$ sebesar 0,139. Maka, Terdapat hubungan positif antara Fasilitas terhadap Tingkat Kunjungan Objek Wisata TGardensebesar 13,9\%.

Berdasarkan hasil uji statistik regresi diperoleh:

1. Secara bersama-sama terdapat pengaruh yang signifikan Fasilitas terhadap Tingkat Kunjungan Objek Wisata T-Garden Kabupaten Deli Serdang (F-hitung $=7,754$; Sig. $=0,008$ ).

2. Variabel Fasilitas secara parsial berpengaruh signifikan terhadap Tingkat Kunjungan Objek Wisata T-Garden Kabupaten Deli Serdang (t-hitung $=2,785$; Sig. $=$ 0,008).

\section{Pengaruh Program Sapta Pesona danFasilitas terhadap Tingkat Kunjungan Objek Wisata}

Persamaan garis linier antara Program Sapta Pesona dan Fasilitas terhadap Tingkat Kunjungan Objek Wisata adalah $\hat{\mathrm{Y}}=0,049 \mathrm{X}_{1}+$ $0,010 \mathrm{X}_{2}+10,590$. dengan nilai koefisien determinasi $\mathrm{R}^{2}$ sebesar 0,278. Maka, Terdapat hubungan positif antara Program Sapta Pesona dan Fasilitas terhadap Tingkat Kunjungan Objek Wisata TGardensebesar 27,8\%.

Berdasarkan hasil uji statistik regresi diperoleh:

1. Secara bersama-sama terdapat pengaruh yang sangat signifikan Program Sapta Pesona dan Fasilitas terhadap Tingkat Kunjungan Objek WisataTGarden Kabupaten Deli Serdang (F-hitung =9,069; Sig. $=0,000$ ).

2. Variabel Program Sapta Pesona secara parsial berpengaruh signifikan terhadap Tingkat Kunjungan Objek Wisata TGarden Kabupaten Deli Serdang(t-hitung $=3,013$; Sig. $=$ 0,004). Sedangkan variabel Fasilitas secara parsial tidak berpengaruh signifikan terhadap Tingkat Kunjungan Objek Wisata T-Garden Kabupaten Deli Serdang (t-hitung $=0,163$; Sig. $=$ $0,871)$.

PEMBAHASAN

1. Pengaruh Program Sapta Pesona terhadap Tingkat Kunjungan Objek Wisata TGarden Kabupaten Deli Serdang

Pada hasil penelitian ini diperoleh bahwa terdapat pengaruh yang sangat signifikan Program Sapta Pesona terhadap Tingkat Kunjungan Objek WisataT-Garden Kabupaten Deli Serdang (F-hitung = 18,487; Sig. $=0,000)$. Hal ini disebabkan program sapta pesona dapat memberikan dan mengembangkan daya tarik dan daya saing pariwisata objek wisata TGarden. Oleh karena itu konsep Program Sapta Pesona didasari pada konsep Sadar Wisata yang terkait 
dengan dukungan dan peran masyarakat sebagai tuan rumah dalam upaya untuk menciptakan lingkungan dan suasana kondusif yang mampu mendorong tumbuh dan berkembangnya industri pariwisata melalui perwujudan tujuh unsur dalam Sapta Pesona.

Sebagaimana dikemukakan menurut Rahim (2012:11-16) bahwa unsur-unsur dari ketujuh Program Sapta Pesona antara lain: (1) Aman, yaitu memberikan rasa tenang, bebas dari rasa takut dan kecemasan bagi wisatawan,

(2) Tertib, yaitu mencerminkan sikap disiplin yang tinggi serta kualitas fisik dan layanan yang konsisten dan teratur serta efisien sehingga memberikan rasa nyaman dan kepastian bagi wisatawan, (3) Bersih, yaitu mencerminkan keadaan yang sehat sehingga memberikan rasa nyaman dan senang bagi wisatawan, (4) Sejuk, yaitu mencerminkan keadaan yang sejuk dan teduh yang akan memberikan perasaan nyaman bagi wisatawan, (5) Indah, yaitu mencerminkan keadaan yang indah dan menarik dan memberikan kesan yang mendalam bagi wisatawan, (6) Ramah, yaitu mencerminkan suasana yang akrab dan terbuka bagi wisatawan, dan (7) Kenangan, yaitu memberikan rasa senang dan kenangan yang indah bagi wisatawan.

Melalui Program Sapta Pesona daya tarik objek wisata yang terdiri dari alam, budaya dan aktivitas serta peristiwa dapat menjadi perhatian sebagai modal dasar pembangunan kepariwisataan sekaligus meningkatkan citra pariwisata (Kodhyat, 2011:27). Dengan demikian, penerapan Program Sapta Pesona pada objek wisata T-Garden dapat mempengaruhi keinginan berkunjung wisatawan dan membuat lama tinggal serta meningkatkan tingkat kunjugan Objek WisataT-Garden Kabupaten Deli Serdang.

\section{Pengaruh Fasilitas terhadap Tingkat Kunjungan Objek WisataT-Garden Kabupaten Deli Serdang}

Pada hasil penelitian ini diperoleh bahwa terdapat pengaruh yang signifikan Fasilitas terhadap Tingkat Kunjungan Objek Wisata TGarden Kabupaten Deli Serdang (Fhitung $=7,754$; Sig. $=0,008$ ). Hal ini disebabkan fasilitas memiliki peranan yang sangat penting dalam meningkatkan kunjungan wisatawan berkunjung ke Objek Wisata TGarden. Sebagaimana dikemukakan oleh Mill (2000:12) bahwa fasilitas merupakan sarana dan prasarana yang mendukung operasional objek wisata untuk mengakomodasi segala kebutuhan wisatawan. Sehingga fasilitas memiliki fungsi yang sangat penting untuk memenuhi kebutuhan wisatawan selama tinggal untuk sementara waktu di daerah tujuan wisata yang dikunjungi.

Hal ini juga dinyatakan oleh Sammeng (2001:39) bahwa salah satu hal penting untuk mengembangkan pariwisata adalah melalui fasilitas (kemudahan). Tidak jarang wisatawan berkunjung ke suatu tempat atau daerah atau negara, karena tertarik oleh kemudahankemudahan yang bisa diperoleh melalui fasilitas. Yoeti (2003:56) juga mengemukakan bahwa fasilitas 
wisata adalah semua fasilitas yang fungsinya memenuhi kebutuhan wisatawan yang tinggal untuk sementara waktu di daerah tujuan wisata yang dikunjunginya, dimana mereka dapat santai menikmati dan berpartisipasi dalam kegiatan yang tersedia di daerah tujuan wisata tersebut. Dengan demikian, fasilitas merupakan faktor yang secara nyata mempengaruhi konsumen untuk mengkonsumsi produk yang ditawarkan. Dengan tersedianya sarana maka akan mendorong calon wisatawan untuk berkunjung dan menikmati Objek Wisata T-Garden dengan waktu yang relatif lama.

\section{Pengaruh Program Sapta Pesona dan Fasilitas Secara Bersama-samaterhadap Tingkat Kunjungan Objek Wisata T- Garden Kabupaten Deli Serdang}

Pada hasil penelitian ini diperoleh bahwa terdapat pengaruh yang sangat signifikan Program Sapta Pesona dan Fasilitas secara bersama-sama terhadap Tingkat Kunjungan Objek Wisata T-Garden Kabupaten Deli Serdang (F-hitung = 9,069; Sig. $=0,000)$. Hal ini disebabkan Program Sapta Pesona merupakan jabaran konsep Sadar Wisata yang terkait dengan dukungan dan peran masyarakat sebagai tuan rumah dalam upaya untuk menciptakan lingkungan dan suasana kondusif yang mampu mendorong tumbuh dan berkembangnya industri pariwisata, melalui perwujudan unsur aman, tertib, bersih, sejuk, indah, ramah, dan unsur kenangan. Sehingga tujuh unsur pesona yang harus diwujudkan bagi terciptanya lingkungan yang kondusif dan ideal bagi berkembangnya kegiatan kepariwisataan di Objek Wisata TGarden dapat mendorong tumbuhnya minat wisatawan untuk berkunjung.

Sebagaimana dikemukakan oleh Rahim (2012:5-6) bahwa Program Sapta Pesona merupakan jabaran konsep Sadar Wisata yang terkait dengan dukungan dan peran masyarakat sebagai tuan rumah dalam upaya untuk menciptakan lingkungan dan suasana kondusif yang mampu mendorong tumbuh dan berkembangnya industri pariwisata melalui perwujudan tujuh unsur dalam Sapta Pesona tersebut. Masyarakat yang sadar wisata memiliki sikap dan tingkah laku yang sesuai dengan Sapta Pesona pariwisata. Sehingga Sapta Pesona yang merupakan jabaran konsep Sadar Wisata sangat terkait dengan dukungan dan peran masyarakat sebagai tuan rumah dalam upaya untuk menciptakan lingkungan dan suasana kondusif yang mampu mendorong tumbuh dan berkembangnya industri pariwisata melalui perwujudan tujuh unsur dalam Sapta Pesona tersebut. Jika masyarakat tidak mendukung Sapta Pesona pariwisata maka wisatawan tidak akan mendapatkan ketenangan dalam berwisata.

$\begin{array}{rrrr} & \text { Dengan } & \text { demikian } & \text { Program } \\ \text { Sapta } & \text { Pesona merupakan } & \text { upaya } \\ \text { untuk } & \text { mendorong } & \text { dan }\end{array}$ mengembangkan industri pariwisata di Objek Wisata T-Gardenmelalui dukungan dan peran masyarakat dalam menciptakan lingkungan dan suasana kondusif di daerah atau destinasi Objek Wisata T-Garden dengan menerapkan program Sapta Pesona. Dengan terwujudnya ketujuh 
unsur Sapta Pesona dalam pengembangan kepariwisataan di Objek Wisata T-Garden akan bermuara pada:meningkatnya minat kunjungan wisatawan ke Objek Wisata T-Garden, tumbuhnya iklim usaha kepariwisataan yang prospektif, dan meningkatnya lapangan pekerjaan dan peluang pendapatan, serta dampak ekonomi multi ganda pariwisata bagi masyarakat.

Meningkatnya Tingkat Kunjungan Objek Wisata T-Garden Kabupaten Deli Serdang juga dipengaruhi oleh peranan fasilitas obbjek wisata. Hal ini disebabkan fasilitas merupakan sarana dan prasarana yang mendukung operasional objek wisata untuk mengakomodasi segala kebutuhan wisatawan yang berkunjung ke Objek Wisata T-Garden. Sebagaimana dikemukakan oleh Sulastiyono (2006:11) bahwa fasilitas adalah penyediaan perlengkapan-perlengkapan fisik untuk memberikan kemudahan kepada para tamu dalam melaksanakan aktivitas-aktivitasnya atau kegiatan-kegiatannya, sehingga kebutuhan-kebutuhan tamu dapat terpenuhi. Faradisa, Budi, dan Minarsih (2016:6) juga menyatakan bahwa fasilitas adalah penyediaan perlengkapan-perlengkapan fisik untuk memberi kemudahan kepada konsumen untuk melaksanakan aktivitas-aktivitas sehingga kebutuhan konsumen dapat terpenuhi. Dengan demikian fasilitas objek wisata yang menarik dan sesuai dengan keinginan yang sedang diminati, akan menjadi daya tarik bagi wisatawan untuk berkunjung dan menikmati fasilitas tersebut sehingga kebutuhan pengunjung terpenuhi, selain itu kebersihan, kelancaran dan jaminan keamanan dari fasilitas juga menjadi nilai tambah untuk menarik konsumen untuk berkunjung ke Objek Wisata T-Garden.

\section{KESIMPULAN}

Berdasarkan hasil penelitian yang telah diuraikan, maka diperoleh kesimpulan bahwa:

1. Terdapat pengaruh yang sangat signifikan Program Sapta Pesona terhadap Tingkat Kunjungan Objek Wisata T-Garden Kabupaten Deli Serdang(F-hitung $=18,487$; Sig. $=0,000)$. Dimana variabel Program Sapta Pesona secara parsial berpengaruh sangat signifikan terhadap Tingkat Kunjungan Objek Wisata TGarden Kabupaten Deli Serdang (t-hitung $=4,300$; Sig. $=0,000$ ). Dengan terdapat hubungan positif dengan kategori sedang antara Program Sapta Pesona terhadap Tingkat Kunjungan Objek Wisata T-Garden sebesar 27,8\%.

2. Terdapat pengaruh yang signifikan Fasilitas terhadap Tingkat Kunjungan Objek Wisata T-Garden Kabupaten Deli Serdang $($ F-hitung $=7,754$; Sig. $=$ 0,008). Dimana variabel Fasilitassecara parsial berpengaruh signifikan terhadap Tingkat Kunjungan Objek Wisata T-Garden Kabupaten Deli Serdang (t-hitung $=2,785$; Sig. $=$ 0,008). Dengan terdapat hubungan positif dengan kategori rendah antara Fasilitas terhadap Tingkat Kunjungan Objek Wisata TGarden sebesar 13,9\%. 
3. Terdapat pengaruh yang sangat signifikan Program Sapta Pesona dan Fasilitas Secara Bersamasama terhadap Tingkat Kunjungan Objek Wisata T-Garden Kabupaten Deli Serdang (F-hitung $=9,069$; Sig. $=0,000)$. Dimana variabel Program Sapta Pesona secara parsial berpengaruh signifikan terhadap Tingkat Kunjungan Objek Wisata TGarden Kabupaten Deli Serdang (t-hitung = 3,013; Sig. $=0,004)$. Namun variabel Fasilitas secara parsial tidak berpengaruh signifikan terhadap Tingkat Kunjungan Objek Wisata TGarden Kabupaten Deli Serdang $(\mathrm{t}$-hitung $=0,163$; Sig. $=0,871)$. Dengan terdapat hubungan positif dengan kategori sedang antara Program Sapta Pesona dan Fasilitas terhadap Tingkat Kunjungan Objek Wisata TGarden sebesar 27,8\%.

\section{DAFTAR PUSTAKA}

Abdulhaji, S., dan Yusuf, I. S. H. 2016. Pengaruh Atraksi, Aksesibilitas, dan Fasilitas terhadap Citra Objek Wisata Danau Tolire Besar Di Kota Ternate. Jurnal Penelitian Humano, Vol. 7, No.2, Halaman: 134-148.

Amirullah. 2016. Penerapan Sapta Pesona Di Pantai Polewali Kabupaten Poliwali Mandar Provinsi Sulawesi Barat. Jurnal Kepariwisataan, Volume. 10, No. 2, Halaman: 15-27. ISSN 1979-7168.

Anonim. 2018. Tentang Kami (T Garden Resort and Ranch). http://http://tgarden.co

(diakses tanggal 10 Juli 2018)

Arikunto, S. 2006. Prosedur Penelitian (Suatu Pendekatan Praktik Edisi Revisi VI). Jakarta: Rineka Cipta.

Departemen Kebudayaan dan Pariwisata Republik Indonesia. 2009. UndangUndang Republik Indonesia Nomor 10 tahun 2009 tentang Kepariwisataan. Jakarta: Departemen Kebudayaan dan Pariwisata Republik Indonesia.

Departemen Pariwisata, Pos dan Telekomunikasi. 1989. Program Sapta Pesona. Jakarta: Departemen Pariwisata, Pos dan Telekomunikasi.

Faradisa, I., Budi, L.H., Minarsih, M. $\quad$ M. 2016. Analisis Pengaruh Variasi Produk, Fasilitas, dan Kualitas Pelayanan Terhadap Minat Beli Ulang Konsumen. Pada Indonesian Coffeeshop Semarang (Icos Café). Journal of Management, Vol. 2, No. 2, Halaman: 1-13.

Ghozali, I. 2006. Aplikasi Analisis Multivariat dengan Program SPSS. Semarang: Undip.

Kesrul, M. 2003. Penyelenggaraan Operasi Perjalanan Wisata. Jakarta: Grasindo.

Kodhyat. 2011. Kepariwisataan Indonesia, Kementerian Kebudayaan dan Pariwisata Indonesia Republik 
Indonesia. Jakarta: Lembaga Studi Pariwisata Indonesia.

Lupioadi, R., dan Hamdani, A. 2008. Manajemen Pemasaran Jasa. Jakarta: Salemba Empat.

Marsongko. 2010. Hands Out Perencanaan Pengembangan Obyek dan Daya Tarik Wisata (ODTW) dan Urban Tourism. $\quad$ STP-Bandung. Pusdiklat Pegawai, Kementrian Kebudayaan dan Pariwisata.

Mill, R. C. 2000. Tourism, The International Business. terjemahan Tri Budi Satrio. Jakarta: Raja Grafindo.

Mukhlas, A. P. S. 2008. Analisis Pengembangan Fasilitas Kawasan Wisata Pantai Trikora Kabupaten Bintan Provinsi Kepulauan Riau. Pekanbaru: Universitas Riau.

Perkasa, C. 2017. Efektivitas Pengelolaan Daya Tarik Wisata Alam oleh Dinas Pariwisata dalam Usaha Meningkatkan Kunjungan Wisatawan Di Kutai Barat. eJournal Administrasi Bisnis, 5(4): 1420-1434.

Prabowo, M. S. 2015. Evaluasi Penerapan Program Sapta Pesona untuk Meningkatkan Kepuasan Wisatawan Di Wisata Alam Pangjugjugan Kabupaten Sumedang (Studi Persepsi Wisatawan). Bandung: Universitas Pendidikan Indonesia.

Rahim, F. 2012. Pedoman Kelompok Sadar Wisata. Jakarta: Direktur Jenderal
Pengembangan Destinasi Pariwisata Kementerian Pariwisata dan Ekonomi Kreatif.

Rahma, F. N., dan Handayani, H. R. 2013. Pengaruh Jumlah Kunjungan Wisatawan, Jumlah Obyek Wisata dan Pendapatan Perkapita terhadap Penerimaan Sektor Pariwisata Di Kabupaten Kudus. Diponegoro Journal of Economics, Volume 2, Nomor 2, Tahun 2013, Halaman 1-9.

Rohmah, M., Zahirman, dan Erlinda, S. 2012. Pengaruh Penggunaan Strategi Pembelajaran Crossword Puzzle terhadap Minat Belajar PKN Siswa Kelas VIII di SMP Negeri 1 Kampar Kiri Tengah Kecamatan Kampar Kiri Tengah Kabupaten Kampar. Riau: Universitas Riau.

Rosita., Marhanah, S., dan Wahadi, W. H. 2016. Pengaruh Fasilitas Wisata dan Kualitas Pelayanan terhadap Kepuasan Pengunjung Di Taman Margasatwa Ragunan Jakarta. Jurnal Manajemen Resort dan Leisure. Vol. 13, No. 1, Halaman: 61-72.

Sammeng, A. M. 2001. Cakrawala Pariwisata. Jakarta: Balai Pustaka.

Sarwono. 2005. Teori dan Praktik Riset Pemasaran SPSS. Yogyakarta: Andi.

Sugiyono. 2010. Metodologi Penelitian Pendidikan, Pendekatan Kuantitatif, 
Kualitatif, dan $R \quad \& \quad D$. Bandung: Alfabeta.

Sulastiyono, A. 2006. Manajemen Penyelenggaraan Hotel. Bandung: Alfabeta.

Sumayang, L. 2003. Dasar-dasar Manajemen Produksi dan Operasi. Jakarta: Salemba.

Suwantoro, G. 2000. Dasar-dasar Pariwisata. Yogyakarta: Andi.

Suyadi. 2015. Pengaruh Program Sapta Pesona terhadap Peningkatan Pengunjung Obyek Wisata Guci Tegal. Jurnal Utilitas, Vol. I, No. 2, Halaman: 157-169. ISSN: 2442-2241.

Syahrul. A. R. 2015. Pengaruh Daya Tarik, Fasilitas dan Aksesibilitas terhadap Keputusan Wisatawan Asing Berkunjung Kembali Ke Aloita Resort di Kab. Kep. Mentawai. Jurnal Pelangi (Research of Education and Development), Vol. 7, No.1, Halaman: 71-82. ISSN: 20851057, E-ISSN: 2460-3740

Tribun Medan. 2018. Tempat Wisata T-Garden ala Bali Baru 25 Persen Rampung Dibangun tapi Pengunjung Sudah
Ramai.http://medan.tribunne ws.com/ 2018/02/02/tempatwisata-t-garden-ala-balimasih-25-persen-terbanguntapi-ramai-dikunjungi (diakses tanggal 3 Mei 2018)

Yoeti, O. A. 2003. Tours and Travel Marketing. Jakarta: Pradnya Paramita.

Sianipar, C., \& Liyushiana, L. (2019). PEMASARAN PARIWISATA DIGITAL OLEH PEMERINTAH KOTA SABANG. Jurnal Darma Agung, 27(3), 11351143.

doi:10.46930/ojsuda.v27i3.37 4

Perwirawati, E., \& Juprianto, J. (2019). STRATEGI

KOMUNIKASI

PEMASARAN

PARIWISATA

KEMARITIMAN DALAM

MENINGKATKAN

KUNJUNGAN

WISATAWAN DI PULAU BANYAK. Jurnal Darma Agung, 27(1), 871 - 883. doi:10.46930/ojsuda.v27i1.14 3 